\title{
THE EFFECT OF SHARING KNOWLEDGE ON HUMAN CAPITAL AND ITS IMPACT ON ORGANIZATIONAL INNOVATION IN PIDIE GOVERNMENT SATKER
}

\author{
Umar, Said Musnadi and Nurdasila \\ Department of Management, Universitas Syiah Kuala, Indonesia \\ http://doi.org/10.35409/IJBMER.2020.3175
}

\begin{abstract}
This study is to test the effect of knowledge sharing on human capital and its impact on organizational innovation. This research is conducted at Pidie Government Satker (Institution. The population is limited only to the Head of Department, Head of Section (Kabag), and Head of Division (Kabid), which amounted to 311 populations. Sampling is taken by simple random sampling method, determined as much as 50 percent of the population so that the sample is 155 respondents. The data is collected using questionnaires. To analyze the data, the Structural Equation Modeling (SEM) method is used in the form of Partial Least Square (PLS). Special for the indirect effects, the authors uses Sobel Calculator to test the model. From the result, we can see that knowledge sharing seen from individual factor effects human capital significantly, knowledge sharing seen from the organizational factor effects human capital significantly, knowledge sharing seen from the technology factor effects human capital significantly, knowledge sharing seen from individual factor effects organizational innovation significantly, knowledge sharing seen from organizational factor effects organizational innovation significantly, knowledge sharing seen from the technology factor effects organizational innovation significantly, human capital effects organizational innovation significantly, there is an effect of knowledge sharing seen from individual factor through human capital on organizational innovation significantly, there is an effect of knowledge sharing seen from organizational factor through human capital on organizational innovation significantly, there is an effect of knowledge sharing seen from the technology factor through human capital on organizational innovation significantly. The all findings show its contribution to update the causality models from the previous, and this new model can support the other research in the further and as reference for the practical managers, especially the object in this research. The research also contains novelty that resides in the integration of the causality theories from the previous researches, and also with the new object that is the Pidie Governmenr Satker. The limitations is also contained that are the number of the variables and the research scope..
\end{abstract}

Keyword: Sharing Knowledge, Human Capital, dan Inovasi Organisasi.

\section{INTRODUCTION}

Innovation in an organization is not something new, grand and luxurious. It requires an appropriate solution to solve various problems with the right method so that it drains the existing 


\section{International Journal of Business Management and Economic Review}

Vol. 3, No. 03; 2020

ISSN: 2581-4664

resources. Talking about innovation in organizations does not have to involve technology that is sophisticated. Organizational innovation is more likely to be a solution to the obstacles being faced in an organization. In this research, the author try to see the figure of the organizational innovation in the scope of Pidie Government Satker, as the government institution in Pidie, Indonesia, in implementing the government program in many development sectors. From the initial survey that was made by authors, the organizational innovation of Pidie Government Satker is still not yet in optimum performance, so it needs to be researched to find out how the oher factors can effect the organization innovation of Pidie Government Satker.

The organizational innovation is provided also from its human capital. Human capital is a characteristic of HR which is determined by the knowledge possessed which is used to create value for the organization (Collins \& Clark, 2003). Organizations with high quality human resources expertise and knowledge are more likely to create higher quality knowledge, so that they will make the right decisions and have better innovation (Hitt, Bierman, Shimizu, \& Kochhar, 2001a).

The role of human resources, the same and even better than other capital factors. With better and developing these roles, it also shifts the concept of human resources management to human capital management. According to (Kearns, 2006) in (Afiouni, 2013) the concept of human capital management is different from human resource management, if human resource management believes that humans are considered significant as costs and must be managed that harm agencies, human capital considers humans as intangible assets and is not an overhead and able to create value. Humans have the advantage of being able to use and propagate better for the individual or for the organization.

Superior human capital will make the agency or organization different from other agencies or organizations. The uniqueness that every human capital brings is what distinguishes it. Because, the importance of the role of human capital is so big in the agency, then, agency management must be more proactive in making its employees as quality human capital. Attention and continuous development must be done to get quality human capital in order to be able to deal with the dynamism of the business environment. With this human capital research, it is hoped that it can fill a little of the research void related to the topic. Quality human capital research is expected to be able to provide high performance to increase productivity and income.

Government agencies need good human capital management. Pidie District Government Work Unit is a local government unit in Aceh Province that provides services to the community in the form of services. The Pidie Regency Regional Government Work Unit has an important role for both the institution and the community, because it provides guarantees and accountability for all government management carried out.

The role of human capital in creating good organizational innovation for the government is needed, especially individual capability and the organizational climate. Educated and trained workforce (individual capability) is needed, because they are the ones who will deal directly with the community and provide services as needed. In addition, the condition of government institutions (the organizational climate) both formal and informal in the work environment also determines and supports the performance of human capital. Although human capital can encourage agency competitiveness, unfortunately in many government agencies currently human resources are rarely given the main attention. Many agency leaders are less aware that the profits derived by the agency actually come from human capital, this is because the activities of the 


\section{International Journal of Business Management and Economic Review}

Vol. 3, No. 03; 2020

ISSN: 2581-4664

agency are seen from a business perspective only. Agency leaders do not see their institution as a unit of business assets that contains unique knowledge and skills, or a unique set of business assets that can differentiate products or services from competitors.

According to (Mayo, 2000), human resources or human capital has five components, namely individual capability, individual motivation, leadership, the organizational climate, and work group effectiveness. Each component has a different role in creating agency human capital which ultimately determines the value of an agency. However, what this study will discuss in more depth is only the component of individual capability and organizational climate. Individual capability is related to knowledge, skills, experience, networks, the ability to achieve results, the potential to develop, and what an individual brings to work from other parts of their lives. While organizational climate is an organizational culture, especially the freedom of an individual to innovate, openness, flexibility and respect for other individuals If an agency wants to win the competition, it must be able to answer the existing challenges. These challenges include collaboration, innovation, adaptation, mastery of technology and markets and the management of agency intellectual assets. These challenges then drive the need for knowledge management (Tobing, 2007). The importance of knowledge management basically starts from the assumption that if an agency wants to develop in the business world, the agency must work smarter. Therefore knowledge sharing is the main source in building agency competitiveness (Sangkala, 2007).

(Tobing, 2007) stated that knowledge sharing is the core of knowledge management value that is owned by agencies will experience an increase due to the process of knowledge sharing. A person's knowledge will not be lost if he shares, even knowledge will diminish and then disappear when he does not share and use the information he has. (Setiarso, Harjanto, Triyono, \& Subagyo, 2009) mentioned the advantage of people who share knowledge is that there are opportunities that can be responded to quickly so that innovation can be created more precisely so as to make the operational costs of agencies can be reduced. If an agency wants to implement knowledge sharing effectively then the culture of knowledge sharing needs to be actively fostered and stimulated (Tobing, 2007).

Knowledge sharing is the interaction and communication between individuals and business units (Reed, Srinivasan, \& Doty, 2009). According to (Small \& Sage, 2005) the success of knowledge sharing depends on the quantity and quality of interaction between employees and the willingness and ability to use knowledge. The emphasis on knowledge triggers the development of the concept of Knowledge Management (KM), assuming important input knowledge in the KM production process emphasizes the ability of agencies to use and combine various knowledge resources that can transform intangible resources into product or process innovations (Grant, 1991).

A group of highly motivated and skilled people is a competitive advantage because it represents agency-specific resources that are important, rare, and difficult to replicate. Institutions with highly skilled and knowledgeable human resources have higher human capital and are more likely to create knowledge, make the right decisions and have better technological innovation (Hitt, Bierman, Shimizu, \& Kochhar, 2001b). (Hsu, Lin, Lawler, \& Wu, 2007) study result showed that organizational learning is related to the development of new knowledge. it is very important for the ability of innovation and organizational performance. (Roos, Roos, Dragonetti, \& Edvinsson, 1997) stated that without the support of agency resources, HR will not 


\section{International Journal of Business Management and Economic Review}

Vol. 3, No. 03; 2020

ISSN: 2581-4664

be able to do much with their ideas. (Nonaka \& Takeuchi, 1995) explained that human capital alone is not beneficial for agencies, if there is no mechanism for HR to share knowledge.

Another opinion was expressed by (Hsu et al., 2007), stated that knowledge sharing is a behavior possessed by someone to disseminate knowledge with other members in an organization so as to create organizational innovation. The estimated parameters between human capital and organizational innovation show a significant relationship, meaning that the higher the intensity of human capital, the higher the organizational innovation. These results indicate that to improve organizational innovation can also be built with human capital. Another opinion expressed by (Hitt et al., 2001b) is that a group of highly committed and highly skilled people (human capital) will be able to build and utilize agency resources by creating agency innovation.

\section{LITERATURE REVIEW \\ Organizational Innovation}

Innovation departs from ideas, come from anywhere, employees, institutional owners, or management. When employees believe that they, and the owner of the institution, have ownership rights to ideas, they can choose to keep their ideas and not hand them over to the owner of the institution (Yessy P, 2015). Innovation begins with creative ideas. This creative idea does not always have to be an attempt to find or achieve something "big" but it can also take the form of a small change effort to improve the current practice.

(West, 2012) said innovation is the introduction of new, better ways of doing things at work. Innovation does not imply absolute renewal and change can be seen as an innovation if the change is considered new to the person, group, or organization that introduces it. Innovations can vary from small innovations to very important innovations.

(Carnegie, 1993) in (Gaspersz \& Fontana, 2011) defined innovation: "As something new or improved that is produced by institutions to create significant added value either directly or indirectly that benefits the institution." One of the main determinants of innovation is the challenge in the organizational environment, because organizational innovation puts a strong emphasis on quality, and managerial support for innovation and is crucial if all individuals want to develop and implement ideas about new ways to better do things. Developing innovation in the workplace begins with developing individual creativity, while new ideas come from motivation, thoughts, and implementation by individuals in the workplace. From the explanation of references above, it concludes that the ability to innovate (innovation capability) is the exploitation of new ideas that are strived for success. Interaction between initiators, implementers and users of innovation can be a dynamic mechanism, there is a transfer of values between elements of innovation that feed forward and feedback According to (Gloet \& Terziovski, 2004), the ability of this innovation provides the potential for emergence effective innovation.

\section{Human Capital}

Human capital is defined as human beings themselves who are personally lent to institutions with their individual capabilities, commitments, knowledge, and personal experience. Although not solely seen from individually but also as a work team that has a personal relationship both inside and outside the institution (Stewart, 1998) in (Totanan, 2004).

Intellectual capital is an intangible asset owned by an institution, and is one of the largest 


\section{International Journal of Business Management and Economic Review}

Vol. 3, No. 03; 2020

ISSN: 2581-4664

assets owned by an institution. Human capital is defined as human beings themselves who are personally lent to institutions with their individual capabilities, commitments, knowledge, and personal experience. Although not solely seen from individually but also as a work team that has a personal relationship both inside and outside the institution (Stewart, 1998) in (Totanan, 2004). According to (Endri, 2010), human capital is as the economic value of HR related to ability, knowledge, ideas, innovation, energy, and commitment.

Human capital is an important thing because it is a source of innovation and strategy renewal that is obtained from brainstorming through laboratory research, management dreams, process reengineering, and improvement of worker skills. Human capital adds value to the institution every day, through motivation, commitment, competence and effectiveness of teamwork. Added value that can be contributed by workers in the form of: competency development owned by the institution, transfer of knowledge from workers to institutions and a change in management culture (Mayo, 2000) in (Rachmawati, 2004). Human capital is the combination of knowledge, skills, innovation and a person's ability to carry out their duties so as to create a value to achieve goals. The formation of added value contributed by human capital in carrying out their duties and work will provide sustainable revenue in the future for an organization (Malhotra, 2011) and (Khalique, Bontis, Shaari, \& Yaacob, 2018)

\section{Knowledge Sharing}

The definition of knowledge according to the Oxford English Dictionary is "facts, information, and skills obtained through experience or education." While Knowledge Transfer International (KTI) in (Sangkala, 2007) had the view that "knowledge is information that has been converted into capabilities for act effectively. The result of knowledge is action ". So it can be concluded that knowledge is information that can be used as a basis for effective decision making. Knowledge sharing is a culture of social interaction that involves the exchange of knowledge, experience, and skills possessed by employees in institutions (Hoegl, Parboteeah, \& Munson, 2003) in (Lin, 2007). (Vries, Hooff, \& Ridder, 2006) defined knowledge sharing as a process in which the exchange of knowledge occurs both explicit and tacit knowledge and then together create new knowledge. Every knowledge sharing behavior consists of bringing (donating knowledge) and getting (collecting knowledge). Donating knowledge is a behavior of communicating the intellectual capital it has to others. Whereas collecting knowledge is the behavior of individuals to consult with other individuals in order to get intellectual capital owned by others.

Knowledge sharing is a series of activities carried out by an organization in managing the knowledge it has. Knowledge sharing provides an opportunity for each member to exchange and provide knowledge to other members. (Hsu et al., 2007) study resulted that knowledge sharing is a behavior owned by someone to disseminate knowledge with other members in an organization so that it can create organizational innovation. The Important factors in the implementation of knowledge sharing According to (Lin, 2007) there are three, namely: individual, organizational, and technology which are then referred to as sharing knowledge enablers. In this research, these three factors is used as variables in the model as derivatives of knowledge sharing.

\section{Research Paradigm and Hypothesis}




\section{International Journal of Business Management and Economic Review}

Vol. 3, No. 03; 2020

ISSN: 2581-4664

From discussion above, it formulates the research paradigm and hypothesis as follows

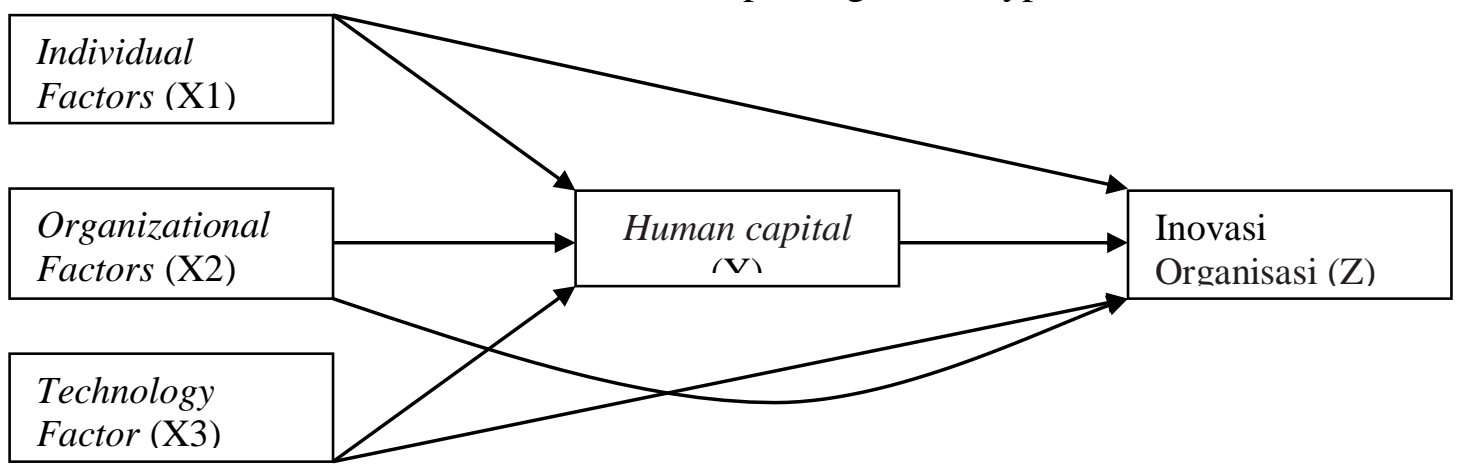

Figure 1. Research Paradigm

H1: knowledge sharing seen from individual factor effects human capital significantly

$\mathrm{H} 2$ : knowledge sharing seen from the organizational factor effects human capital significantly

H3: knowledge sharing seen from the technology factor effects human capital significantly

H4: knowledge sharing seen from individual factor effects organizational innovation significantly

H5: knowledge sharing seen from organizational factor effects organizational innovation significantly

H6: knowledge sharing seen from the technology factor effects organizational innovation significantly

H7: human capital effects organizational innovation significantly

H8: There is an effect of knowledge sharing seen from individual factor through human capital on organizational innovation significantly

H9: There is an effect of knowledge sharing seen from organizational factor through human capital on organizational innovation significantly

H10: There is an effect of knowledge sharing seen from the technology factor through human capital on organizational innovation significantly

\section{METHOD}

This research is conducted at Pidie Government Satker (Institution), while the object is limited to the knowledge sharing variable seen from individual factors, organizational factors and technology factors, human capital and organizational innovation. The population is limited only to the Head of Department, Head of Section (Kabag), and Head of Division (Kabid), which amounted to 311 population. Sampling is taken by simple random sampling method, determined as much as 50 percent of the population so that the sample is 155 respondents. The data is collected using questionnaires. In analyzing the data, the Structural Equation Modeling (SEM) method is used in the form of Partial Least Square (PLS). SEM is divided into two types, namely Covarian-based Structural Equation Model (CB-SEM) and Partial Least Square - Structural Equation Modeling (PLS-SEM) (Latan \& Ghozali, 2012). Special for the indirect effects, the authors uses Sobel Calculator to test the model. 


\section{RESULT}

The result from SEM-PLS processing describe the R-square as follows

1. Human Capital is influenced by the Individual Factor, Organizational Factor and Technological Factor by 96.9 percent, and the remaining 3.1 percent is influenced by other variables outside this research model.

2. Organizational Innovation is influenced by the Individual Factor, Sharing Organizational Factor and Technology Factor and Human Capital by 95.3 percent and the remaining 4.7 percent is influenced by other variables outside this research model.

Other than that, the p-value of all direct effect hypotheses show there are all smaller than 0.05, which means that all the direct effect hypotheses have proven. And for the $\mathrm{p}$-value of all indirect effect hypotheses, by using the Sobel test calculator it provides the p-value smaller than 0.05 as well, so the all indirect effect hypotheses have proven too. And analysis of the coefficients can be described as follows.

\section{Direct Effect}

From the data processing, it provides the direct effect coefficient as follows.

Table 1. Direct Effect Coefficient

\begin{tabular}{|l|l|l|}
\hline Variabel & Human Capital & Inovasi Organisasi \\
\hline Human Capital & & 0.529 \\
\hline Individual Factor & 0.358 & 0.022 \\
\hline Organziational Factor & 0.063 & 0.164 \\
\hline Technology Factor & 0.571 & 0.313 \\
\hline
\end{tabular}

The Effect of Individual Factors on Human Capital

The result provides that the higher the intensity of knowledge sharing seen from individual factors, the higher the human capital. The result of this study is in line with research conducted by (Widjajanti \& Widodo, 2014), Estimating parameters between knowledge sharing seen from individual factors with human capital show significant results, meaning that the higher the intensity of knowledge sharing seen from individual factors, the higher human capital. These results indicate that to increase human capital can be done by increasing knowledge sharing seen from individual factors.

(Kogut \& Zander, 1992) also said the same thing, organizational learning emphasizes interaction patterns between HR to achieve meaningful goals. The view of knowledge-based organizations is started by individuals and institutions become superior in their ability to integrate knowledge across individuals, so sharing knowledge seen from individual factors is very influential and very influential in increasing human capital.

The Effect of Organiziational Factors on Human Capital

The result explains that the higher the intensity of knowledge sharing seen from 


\section{International Journal of Business Management and Economic Review}

Vol. 3, No. 03; 2020

ISSN: 2581-4664

organizational factors, the higher the human capital. This is in line with research conducted by (Widjajanti \& Widodo, 2014), knowledge sharing seen from organziational factors has a significant and positive effect on human capital, meaning that the higher the intensity of knowledge sharing seen from organziational factors, the higher the human capital will be. These results indicate that to increase human capital can be done by increasing knowledge sharing seen from organizational factors.

(Kogut \& Zander, 1992) also said the same thing, organizational learning emphasizes the patterns of interaction between HR to achieve meaningful goals. The view of knowledge-based organizations is started by individuals and institutions become superior in their ability to integrate knowledge across individuals, so sharing knowledge seen from organziational factors plays an important and very influential role in increasing human capital.

\section{The Effect of Technology Factors on Human Capital}

The result explains that the higher the intensity of knowledge sharing seen from the technology factor, the higher the human capital. In line with (Widjajanti \& Widodo, 2014), the estimated parameters between knowledge sharing seen from technology factors and human capital show significant results, meaning that the higher the intensity of knowledge sharing seen from technology factors, the higher human capital. These results indicate that to increase human capital can be done by increasing knowledge sharing seen from the technology factor. (Kogut \& Zander, 1992) also said the same thing, organizational learning emphasizes interaction patterns between HR to achieve meaningful goals. The view of knowledge-based organizations is started by individuals and institutions become superior in their ability to integrate knowledge across individuals, so sharing knowledge seen from the technology factor is very influential in increasing human capital.

\section{The Effect of Individual Factors on Organizational Innovation}

The result figures that the higher the intensity of knowledge sharing seen from individual factors, the higher the organizational innovation. This research is in line with (Widjajanti \& Widodo, 2014), which suggested that to improve organizational innovation can be built by sharing knowledge seen from individual factors. Organizational innovation is also as a successful application of creative ideas in the company, and it needs the organizational mechanisms to adapt in dynamic environments. Therefore, organizations are required to create judgments and new ideas, and offer innovative products. With innovation, this is a way to continue to develop organizations through the introduction of new technologies, new applications in products and services, development of new markets and introducing new forms of organization. Integration of various aspects of innovation in turn forms the arena of innovation. The research of (Hsu et al., 2007) resulted that sharing knowledge seen from individual factors are behaviors that a person has to disseminate knowledge to other members in an organization so it has a strong influence on organizational innovation.

Likewise with several studies conducted by (Lado \& Wilson, 1994), (Lepak \& Snell, 2002), and (Chu, Lee, \& Chao, 2012) knowledge sharing seen from individual factors plays an important role in an organization, especially in increasing organizational innovation meaning with the higher the intensity of knowledge sharing seen from individual factors, the higher the organizational innovation. 


\section{International Journal of Business Management and Economic Review}

Vol. 3, No. 03; 2020

ISSN: 2581-4664

The Effect of Organziational Factors on Organizational Innovation

The result described that the higher the intensity of knowledge sharing seen from organizational factors, the higher the organizational innovation. In line with research conducted by Widjajanti (2014) also stated the same thing that to improve organizational innovation is built by sharing knowledge seen from organizational factors. (Hsu et al., 2007) also said the same thing that sharing knowledge is a behavior that a person has to spread knowledge with other members in an organization so that it can create organizational innovation.

Several other studies conducted by (Lado \& Wilson, 1994), (Lepak \& Snell, 2002), and (Chu et al., 2012) revealed that knowledge sharing seen from organziational factors play an important role in an organization, especially in increasing organizational innovation meaning with higher the intensity of knowledge sharing is seen from the organizational factors, the higher organizational innovation.

\section{The Effect of Technology Factors on Organizational Innovation}

The result reveals that the intensity of knowledge sharing is seen from the technology factor, the higher the technology factor, the higher the organizational innovation. Agreeing with research conducted by (Widjajanti \& Widodo, 2014), to improve organizational innovation can be built by sharing knowledge. Innovation is the way to continue to develop organizations through the introduction of new technologies, new applications in products and services, and introducing new forms of organization. Integration of various aspects of innovation in turn forms the arena of innovation. (Lin, 2007) described that knowledge sharing is seen from the technology factor is a behavior possessed by someone to disseminate knowledge to other members in an organization so that can create organizational innovation.

Research conducted by (Lado \& Wilson, 1994), (Lepak \& Snell, 2002), and (Chu et al., 2012) also mapped the same thing that knowledge sharing seen from technology factors influences the increase in organizational innovation, meaning that the higher the intensity of knowledge sharing seen from the technology factor, the higher organizational innovation.

\section{The Effect of Human Capital on Organizational Innovation}

The result reveals that the higher the intensity of human capital, the higher the organizational innovation. Also in line with (Widjajanti \& Widodo, 2014), that to improve organizational innovation can be done by increasing human capital. The fundamental problem of an organization is how to encourage HR to contribute their knowledge to benefit the organization. People may be reluctant to share knowledge, for fear of losing ownership, important positions or superiority. Therefore, in the interest of the organization, managers must emphasize the development of capabilities and commitment (willingness and desire to contribute to the success of the institution. Human capital must therefore involve HR competencies (for example: Skills, knowledge and capabilities) and also their commitment (for example: willingness to dedicate life and work for institutions.) (Hitt et al., 2001b) a group of highly committed and highly skilled people (human capital) capable of building and utilizing institutional resources by creating innovative institutions.

(Klane, 1941) also said the same thing that sharing knowledge is a behavior possessed by someone to disseminate knowledge to other members in an organization so as to create 


\section{International Journal of Business Management and Economic Review}

Vol. 3, No. 03; 2020

ISSN: 2581-4664

organizational innovation. In the interest of the organization the manager must emphasize the development of capabilities and commitment (willingness and desire to contribute to the success of the institution. So human capital must involve HR competencies (for example: Skills, knowledge and capabilities) and also their commitment (for example: willingness to dedicate life and work for institutions).

\section{Indirect Effect}

Table 2. Indirect Effect Coefficient

\begin{tabular}{|l|l|l|}
\hline Effect & $\begin{array}{l}\text { Indirect } \\
\text { Effect }\end{array}$ \\
\hline $\begin{array}{l}\text { Individual Factors } \\
\text { Innovation }\end{array}$ & 0.190 \\
\hline $\begin{array}{l}\text { Organziational Factors } \\
\text { Innovation }\end{array}$ & 0.033 \\
\hline $\begin{array}{l}\text { Technology Factor } \\
\text { Innovation }\end{array}$ & 0.30 Human Capital $>$ Organizational \\
\hline
\end{tabular}

The statistical test result for indirect effect in the table above shows that if Knowledge Sharing of Individual Factors through Human Capital changes by 1 unit, it will affect the Organizational Innovation by 0.190 unit. If Knowledge Sharing of Organizational Factors through Human Capital experiences a change of 1 unit, it will affect the Organizational Innovation by 0.033 unit. If Knowledge Sharing of Technology Factors through Human Capital changes by 1 unit, it will affect the Organizational Innovation by 0.302 Likert scale.

\section{CONCLUSION}

From the result, we can see that knowledge sharing seen from individual factor effects human capital significantly, knowledge sharing seen from the organizational factor effects human capital significantly, knowledge sharing seen from the technology factor effects human capital significantly, knowledge sharing seen from individual factor effects organizational innovation significantly, knowledge sharing seen from organizational factor effects organizational innovation significantly, knowledge sharing seen from the technology factor effects organizational innovation significantly, human capital effects organizational innovation significantly, there is an effect of knowledge sharing seen from individual factor through human capital on organizational innovation significantly, there is an effect of knowledge sharing seen from organizational factor through human capital on organizational innovation significantly, there is an effect of knowledge sharing seen from the technology factor through human capital on organizational innovation significantly. The all findings show its contribution to update the causality models from the previous, and this new model can support the other research in the further and as reference for the practical managers, especially the object in this research. The research also contains novelty that resides in the integration of the causality theories from the previous researches, and also with the new object that is the Pidie Governmenr Satker. The limitations is also contained that are the number of the variables and the research scope. 
Vol. 3, No. $03 ; 2020$

ISSN: 2581-4664

\section{REFERENCES}

Afiouni, F. (2013). Human capital management: a new name for HRM? International Journal Learning and Intellectual Capital, 10(1), 18-34.

Carnegie, R. (1993). Managing the Innovating Enterprise: Australian Companies Competing with the World's Best. Melbourne: Business Library: Business Council of Australia.

Chu, P. Y., Lee, G. Y., \& Chao, Y. (2012). Service quality, customer satisfaction, customer trust, and loyalty in an e-banking context. Social Behavior and Personality An International Journal, 4O(8), 1271-1284. https://doi.org/https://doi.org/10.2224/sbp.2012.40.8.1271

Collins, C. J., \& Clark, K. D. (2003). Strategic Human Resource Practices, Top Management Team Social Networks, and Firm Performance: The Role of Human Resource Practices in Creating Organizational Competitive Advantage. The Academy of Management Journal, 46(6), 740-751. https://doi.org/10.2307/30040665

Endri. (2010). Peran Human Capital Dalam Meningkatkan Kinerja Perusahaan: Suatu Tinjauan Teoritis Dan Empiris. Jurnal Administrasi Bisnis, 6(2), 179-190.

Gaspersz, V., \& Fontana, A. (2011). Lean Six Sigma for Manufacturing and Service Industries. Bogor: Gramedia Pustaka Utama.

Gloet, M., \& Terziovski, M. (2004). Exploring the relationship between knowledge management practices and innovation performance. Journal of Manufacturing Technology Management, 15(5), 402-409. https://doi.org/10.1108/17410380410540390

Grant, R. M. (1991). The Resource-Based Theory of Competitive Advantage: Implications for Strategy Formulation. California Management Review, 33(3), 114-135. https://doi.org/10.1016/B978-0-7506-7088-3.50004-8

Hitt, M. A., Bierman, L., Shimizu, K., \& Kochhar, R. (2001a). Direct and Moderating Effects of Human Capital on Strategy and Performance in Professional Service Firms: A ResourceBased Perspective. The Academy of Management Journal, 44(1), 13028. https://doi.org/10.2307/3069334

Hitt, M. A., Bierman, L., Shimizu, K., \& Kochhar, R. (2001b). Direct and Moderating Effects of Human Capital on Strategy and Performance in Professional Service Firms: A ResourceBased Perspective. The Academy of Management Journal, 44(1), 13028. https://doi.org/10.2307/3069334

Hoegl, M., Parboteeah, K. P., \& Munson, C. L. (2003). Team-Level Antecedents of Individuals' Knowledge Networks. Decision Sciences, 34(4), 741-770. https://doi.org/https://doi.org/10.1111/j.1540-5414.2003.02344.x

Hsu, I.-C., Lin, C. Y. Y., Lawler, J. J., \& Wu, S.-H. (2007). Toward a Model of Organizational Human Capital Development: Preliminary Evidence from Taiwan. Asia Pacific Business Review, 13(2), 251-257. https://doi.org/10.1080/13602380701233547

Kearns, P. (2006). Evaluating the ROI from Learning: How to Develop Value-based Training. Human Resource Management International Digest, 14(1). https://doi.org/https://doi.org/10.1108/hrmid.2006.04414aae.002

Khalique, M., Bontis, N., Shaari, J. A. N. Bin, \& Yaacob, M. R. (2018). Intellectual capital and organisational performance in Malaysian knowledge-intensive SMEs. International Journal of Learning and Intellectual Capital, 15(1). https://doi.org/10.1504/IJLIC.2018.088345

Klane, R. (1941). Sharing Knowledge. New Jersey: Prentice Hall. 


\section{International Journal of Business Management and Economic Review}

Vol. 3, No. 03; 2020

ISSN: 2581-4664

Kogut, B., \& Zander, U. (1992). Knowledge of the Firm, Combinative Capabilities, and the Replication of Technology. Organization Science, 3(3). https://doi.org/10.1287/orsc.3.3.383

Lado, A. A., \& Wilson, M. C. (1994). Human Resource Systems and Sustained Competitive Advantage: A Competency-Based Perspective. Academy of Management Review, 19(4). https://doi.org/https://doi.org/10.5465/amr.1994.9412190216

Latan, H., \& Ghozali, I. (2012). Partial Least Square: Konsep, Teknik, dan Aplikasi SmartPLS 2.0 M3. Semarang: Badan Penerbit Universitas Diponogero.

Lepak, D. P., \& Snell, S. A. (2002). Examining the Human Resource Architecture: The Relationships Among Human Capital, Employment, and Human Resource Configurations. Journal of Management, 28(4), 517-543. https://doi.org/10.1016/S0149-2063(02)00142-3

Lin, H.-F. (2007). Knowledge sharing and firm innovation capability: an empirical study. International Journal of Manpower, 28(3/4), 315-332. https://doi.org/https://doi.org/10.1108/01437720710755272

Malhotra, N. K. (2011). Basic Marketing Research (4th ed.). London: Pearson.

Mayo, A. (2000). The role of employee development in the growth of intellectual capital. Personnel Review, 29(4), 521-533. https://doi.org/10.1108/00483480010296311

Nonaka, I. o, \& Takeuchi, H. (1995). The Knowledge-creating Company: How Japanese Companies Create the Dynamics of Innovation. United Kingdom: Oxford University Press.

Rachmawati, D. (2004). Intellectual capital dan kinerja bisnis: studi empiris pada industri di Indonesia: hasil penelitian Penelitian dosen muda. Surabaya: Fakultas Ekonomi, Universitas Katolik Widya Mandala.

Reed, K. K., Srinivasan, N., \& Doty, D. H. (2009). Adapting Human and Social Capital to Impact Performance: Some Empirical Findings From the U.S. Personal Banking Sector. Journal of Manageria, XXI(1), 36-57.

Roos, J., Roos, G., Dragonetti, N. C., \& Edvinsson, L. (1997). Intellectual Capital Navigating the New Business Landscape (1st ed.). https://doi.org/10.1007/978-1-349-14494-5

Sangkala. (2007). Knowledge management: Suatu pengantar memahami bagaimana organisasi mengelola pengetahuan sehingga menjadi organisasi yang unggul. Medan: Raja Grafindo Persada.

Setiarso, B., Harjanto, N., Triyono, \& Subagyo, H. (2009). Penerapan Knowledge Management pada Organisasi. Medan: Graha Ilmu.

Small, C. T., \& Sage, A. P. (2005). Knowledge management and knowledge sharing: A review. Information Knowledge Systems Management, 5(3), 153-169.

Stewart, T. A. (1998). Intellectual Capital: The new wealth of organization. New York: Crown Business.

Tobing, P. L. (2007). Knowledge management: Konsep, arsitektur dan implementasi (Ed. 1). Yogyakarta: Graha Ilmu.

Totanan, C. (2004). Peranan intellectual capital dalam penciptaan nilai untuk keunggulan bersaing. Palu: Usahawan.

Vries, R. E. de, Hooff, B. Van den, \& Ridder, J. A. de. (2006). Explaining Knowledge Sharing The Role of Team Communication Styles, Job Satisfaction, and Performance Beliefs. Communication Research, 33(2). https://doi.org/DOI: 10.1177/0093650205285366

West, M. A. (2012). Effective Teamwork: Practical Lessons from Organizational Research (3rd ed.). United States: Wiley-Blackwell. 
International Journal of Business Management and Economic Review

Vol. 3, No. $03 ; 2020$

ISSN: 2581-4664

Widjajanti, K., \& Widodo. (2014). Pengembangan Inovasi Organisasi Berbasis Human Capital, Sharing Knowledge Dan Pembelajaran Organisasional. EKOBIS, 15(1), 86-101.

Yessy P, H. (2015). Pemimpin Inovatif dan Transformator di Era Modern. 